\title{
Correction to: Direct antivirals working against the novel coronavirus: azithromycin (DAWn-AZITHRO), a randomized, multicenter, open-label, adaptive, proof-of- concept clinical trial of new antivirals working against SARS-CoV-2-azithromycin trial
}

Iwein Gyselinck ${ }^{1 *}$, Laurens Liesenborghs ${ }^{1}$, Ewout Landeloos ${ }^{1}$, Ann Belmans $^{2}$, Geert Verbeke ${ }^{2}$, Peter Verhamme ${ }^{1}$, Robin Vos ${ }^{1}$, W. Janssens ${ }^{1}$ and on behalf of the DAWn-Azithro consortium

Correction to: Trials 22, 126 (2021)

https://doi.org/10.1186/s13063-021-05033-x

Following publication of the original article [1], we were notified of a typo in one of the authors' names.

Originally published author name: Laurens Liesenborgs.

Corrected author name: be Laurens Liesenborghs.

The original article has been corrected.

\section{Author details}

${ }^{1}$ Katholieke Universiteit Leuven Universitaire Ziekenhuizen Leuven, Leuven,

Belgium. ${ }^{2}$ Interuniversity Institute for Biostatistics and Statistical

Bioinformatics, Leuven, Belgium.

Published online: 05 March 2021

\section{Reference}

1. Gyselinck I, et al. Direct antivirals working against the novel coronavirus: azithromycin (DAWn-AZITHRO), a randomized, multicenter, open-label, adaptive, proof-of-concept clinical trial of new antivirals working against SARS-CoV-2-azithromycin trial. Trials. 2021;22:126. https://doi.org/10.1186/ s13063-021-05033-X.

The original article can be found online at https://doi.org/10.1186/s13063 021-05033-x

* Correspondence: iwein.gyselinck@kuleuven.be

${ }^{1}$ Katholieke Universiteit Leuven Universitaire Ziekenhuizen Leuven, Leuven, Belgium

(c) The Author(s). 2021 Open Access This article is licensed under a Creative Commons Attribution 4.0 International License, which permits use, sharing, adaptation, distribution and reproduction in any medium or format, as long as you give appropriate credit to the original author(s) and the source, provide a link to the Creative Commons licence, and indicate if changes were made. The images or other third party material in this article are included in the article's Creative Commons licence, unless indicated otherwise in a credit line to the material. If material is not included in the article's Creative Commons licence and your intended use is not permitted by statutory regulation or exceeds the permitted use, you will need to obtain permission directly from the copyright holder. To view a copy of this licence, visit http://creativecommons.org/licenses/by/4.0/. The Creative Commons Public Domain Dedication waiver (http://creativecommons.org/publicdomain/zero/1.0/) applies to the data made available in this article, unless otherwise stated in a credit line to the data. 